\title{
Konsep Pendidikan Al-Qabisy Dan M. Rasyid Ridha (Koedukasi Dan Kurikulum)
}

\author{
Muh. Dahlan Thalib
}

Sekolah Tinggi Agama Islam Negeri

\begin{abstract}
Kurikulum pendidikan Islam merupakan bagian integral yang sangat vital dalam capaian hasil atau tujuan pendidikan. Koedukasi berarti percampuran antara laki-laki dan perempuan dalam suatu kelas, sistem pendidikan yang dilakukan melalui proses belajar mengajar yang menggambungkan pria dan wanita dalam suatu ruangan (kelas), atau sering pula dikenal dengan pendidikan campuran.

Penerapan sistem koedukasi dalam pendidikan Islam bagi Al-Qabisy bahwa tidak baik anak pria dan wanita bercampur dalam suatu kelas, karena dikhawatirkan rusak moralnya, maka pemisahan tempat pendidikan wajib dilakukan demi terjaga keselamatan anak-anak dari penyimpangan-penyimpangan akhlak. Sedangkan Rasyid Ridha menolak adanya manfaat dari koedukasi, dan menganggap bahwa koedukasi bukan sekedar memiliki kekurangan, namun dapat mendatangkan malapetaka, utamanya kaum wanita.

Al-Qabisy mengklasifikasi kurikulum pendidikan Islam ke dalam dua bagian besar yaitu ilmu-ilmu asasi/wajib (ijbari) dan ilmu-ilmu yang bukan asasi/tidak wajib (ikhtiyariy). Sedangkan Rasyid Ridha lebih menekankan kurikulum pada aspek muatan kurikulum ilmu agama dan umum, Implementasi dari kurikukum yang ia terapkan di Madrasah tampaknya memilah antara ruang ilmu peribadatan yang wajib dilakukan pada setiap pelajar. Dalam hal ini aspek pertama, masalah materi Alquran dan Hadis harus diajarkan dan diimpelementasikan secara asasi kepada lingkup lembaga pendidikan. Sementara aspek kedua, yakni aspek mu'amalah, diserahkan kepada komponen pelaksana/pengelola dan penanggungjawab pendidikan yang dapat dikondisionalkan.
\end{abstract}

\section{PENDAHULUAN}

\section{A. Latar Belakang}

Posisi manusia sebagai homo educandum (makhluk yang dapat didik), homo education (makhluk pendidik), dan homo religious (makhluk beragama) mengindikasikan bahwa perilaku keberagamaan manusia, dapat diarahkan melalui pendidikan. Pendidikan yang dimaksud di sini adalah pendidikan Islam, yakni dengan cara membimbing dan mengasuhnya agar dapat memahami, menghayati ajaran-ajaran Islam, sehingga tampak perilaku keberagamaan secara simultan dan terarah pada tujuan hidup manusia. Pendidikan Islam merupakan pendidikan yang 
sangat ideal, ${ }^{1}$ karena menyelaraskan antara pertumbuhan fisik dan mental, jasmani dan rohani, pengembangan individu dan masyarakat, serta dunia dan akhirat.

Menanamkan perilaku keberagamaan terhadap peserta didik diharapkan memberikan pengaruh bagi pembentukan jiwa keagamaan. Besar kecil pengaruh yang dimaksud sangat tergantung berbagai faktor yang dapat memotivasi untuk memahami nilai-nilai agama, sebab pendidikan agama pada hakekatnya merupakan pendidikan nilai. Oleh karena itu, pendidikan agama lebih dititik beratkan pada bagaimana membentuk kebiasaan yang selaras dengan tuntunan agama. $^{2}$ Disinilah letak pentingnya rumusan kurikulum yang mampu mengakomodir dan terjewantahkan ke seluruh dimensi ranah pembelajaran di sekolah (madrasah). Letak permasalahan selanjutnya adalah kurikulum Pendidikan Islam yang selama ini diterapkan belum mampu secara maksimal menjadi tolok ukur utama keberhasilan pendidikan secara simultan.

Sistem pendidikan Islam memiliki keunikan tersendiri, akibat adanya aturan-aturan nilai yang terkadang dianggap menyimpang dari pemenuhan nilainilai pendidikan Islami. Salah satu yang urgen dikaji bahwa pendidikan berlaku kepada seluruh manusia, tidak mengenal adanya perbedaan streotipe jenis kelamin. Namun terdapat pandangan berbeda dalam kesamaan pria dan wanita dalam sistem pemerolehan pendidikan dengan memandang sisi posistif dan negatifnya.

Kaitannya dengan komponen kurikulum dan sistem koedukasi di atas, maka tujuan pendidikan Islam melalui sistem persekolahan/madrasah patut diberikan penekanan yang istimewa. Hal ini disebabkan oleh pendidikan sekolah/madrasah mempunyai program yang teratur, bertingkat dan mengikuti syarat yang jelas dan ketat. Hal ini mendukung program pendidikan Islam yang lebih akomodatif, transformatif dan relevan dengan tujuan pendidikan Islam. Para tokoh pembaharu dan pemikir Pendidikan Islam menanggapi tentang kurikulum dan koedukasi pendidikan dengan beragam pandangan. Abu al-Hasan al-Qabisy

${ }^{1}$ Pendidikan Islam mencakup kehidupan manusia seutuhnya, memperhatikan segi akidah, ibadah, serta akhlak, bahkan pendidikan dapat bermakna merubah dan memindahkan nilai kebudayaan kepada masayarakat dan individu. Hasan Langgulung, Pendidikan dan Peradaban Islam; Suatu Analisa Sosio-Psikologi, (Jakarta, Pustaka Al-Husna, 1985,), h. 3. Lihat juga Mappanganro, Implementasi Pendidikan Islam di Sekolah (Ujungpandang: Yayasan Ahkan, 1996), h. 10 .

${ }^{2}$ Jalaluddin, Psikologi Agama (Cet.I; Jakarta: Grafindo Persada, 1996), h. 206. Pengaruh pembentukan jiwa keagamaan dan perilaku keberagamaan pada lembaga pendidikan, khususnya pada lembaga pendidikan formal banyak tergantung dari bagaimana karakteristik pendidikan agama yang diterapkan. Sekolah atau madrasah dalam perspektif Islam, berfungsi sebagai media realisasi pendidikan berdasarkan tujuan pemikiran, aqidah dan syariah dalam upaya penghambaan diri terhadap Allah dan mentauhidkan-Nya sehingga manusia terhindar dari penyimpangan fitrahnya. Abdurrahman al-Nahdlawi, Ushul al-Tarbiyah al-Islamiyah wa Asalibuha fi al-Bayt wa alMadrasah wa al-Mujtama' diterjemahkan oleh Shibabuddin dengan judul Pendidikan Islam di Rumah, Sekolah dan Masyarakat (Cet. II; Jakarta: Gema Insani Press, 1995), h. 152.

Jurnal ..........., Volume ....... No. ......... 2012 
dan Rasyid Ridha adalah dua sosok pemikir Pendidikan Islam yang memiliki pandangan signifikan tentang kedua obyek kajian pendidikan ini.

\section{B. Rumusan Masalah}

Menyimak uraian latar belakang di atas, tulisan ini akan membahas beberapa pokok permasalahan yang relevan, sebagai berikut:

1. Bagaimana biografi dan pembaharuan pemikiran Al-Qabisy dan Rasyid Ridha dalam dunia pendidikan Islam pada umumnya?

2. Bagaimana maksud/pengertian kurikulum dan koedukasi tersebut?

3. Bagaimana konsep pendidikan Al-Qabisy dan Rasyid Ridha tentang koedukasi dan kurikulum?

\section{PEMBAHASAN}

A. Biografi al-Qabisy dan Rasyid Ridha sebagai Tokoh Pemikir Pendidikan Islam.

1. Biografi Al-Qabisy dan Pandangan Umumnya tentang Pendidikan.

Nama lengkap Al-Qabisiy adalah Abu Al-Hasan Muhammad bin Khalaf Al-Ma'arifi Al-Qairawaniy. Al-Qabisiy adalah penisbahan kepada sebuah bandar yang terdapat di Tunis. Kalangan ulama lebih mengenal namanya dengan sebutan Al-Qabisiy. Ia lahir di Kota Qairawan Tunisia pada tahun $324 \mathrm{H}_{-} 935 \mathrm{M}^{3}$ Literatur-literatur tidak menyebutkan perihal kedudukan orang tuanya. Barangkali Al-Qabisiy bukan dari keturunan ulama yang termasyhur, atau bangsawan ataupun hartawan sehingga asal keturunannya tidak banyak digambarkan sejarah, namun namanya terkenal setelah ia menjadi ilmuan yang berpengaruh dalam dunia Islam.

Semasa kecil dan remajanya belajar di Kota Qairawan. Ia mulai mempelajari Al-Qur'an, hadits, fikih, ilmu-ilmu bahasa Arab dan Qira'at dari beberapa ulama yang terkenal di kotanya. Di antara ulama yang besar sekali memberi pengaruh pada dirinya adalah Abu Al-'Abbas Al-Ibyani yang amat menguasai fikih mazhab Malik. Al-Qabisiy pernah mengatakan tentang gurunya ini: "saya tidak pernah menemukan di Barat dan di Timur ulama seperti Abu al-'Abbas. Guru-guru lain yang banyak ia menimba ilmu dari mereka adalah Abu Muhammad Abdullah bin Mansur Al-Najibiy, Abdullah bin Mansur Al-Ashal, Ziyad bin Yunus AlYahsabiy, Ali Al-Dibagh dan Abdullah bin Abi Zaid. ${ }^{4}$

Al-Qabisiy pernah sekali melawat ke wilayah Timur Islam dan menghabiskan waktu selama 5 tahun, untuk menunaikan ibadah haji dan sekaligus

3 Ali al-Jumbulati, Dirasatun Muqaranatun fit Tarbiyyatil Islamiyyah, terj. M. Arifin, dengan judul Perbandingan Pendidikan Islam, (Jakarta: Rineka Cipta, 1994), hal. 76. Menurut data yang ada, bahwa ia lahir pada bulan Rajab, 224 M (13 Mei 936 M), dan wafat di negeri asalnya pada tanggal 3 R. Awal 403 H (23 Oktober 1012 M).

${ }^{4}$ Abdullah al-Amin al-Nu'my, Kaedah dan Tekhnik Pengajaran Menurut Ibnu Khaldun dan Al-Qabisy, (Jakarta: t.pt., 1995), h.184 
menuntut ilmu. Ia pernah menetap di bandar-bandar besar seperti Iskandariyah dan Kairo (Negara Mesir) serta Hejaz dalam waktu yang relatif tidak begitu lama. Di Iskandariyah ia pernah belajar pada Ali bin Zaid Al-Iskandariy, seorang ulama yang masyhur dalam meriwayatkan hadits Imam Malik dan mendalami mazhab fikihnya. ${ }^{5}$ Al-Qabisiy mengajar pada sebuah madrasah yang diminati oleh penunut-penuntut ilmu. Madrasah ini lebih memfokuskan pada ilmu hadits dan fikih. Pelajar-pelajar yang menuntut ilmu di madrasah ini banyak yang datang dari Afrika dan Andalus. Murid-muridnya yang terkenal adalah Abu Imran Al-Fasiy, Abu Umar Al-Daniy, Abu Bakar bin Abdurrahman, Abu Abdullah Al-Maliki, Abu Al-Qasim Al-Labidiy Abu Bakar 'Atiq Al-Susiy dan lain-lain. ${ }^{6}$

Al-Qabisiy terkenal luas pengetahuannya dalam bidang hadits dan fikih di samping juga sastera Arab. ${ }^{7}$ Ia menjadi rujukan ummat dan dibutuhkan untuk menjawab masalah-masalah hukum Islam, maka ia diangkat menjadi mufti dinegerinya. Sebenarnya, ia tidak menyukai jabatan ini, karena ia memiliki sifat tawadlu ' (merendah diri), wara' (bersih dari dosa) dan zuhud (tidak mencintai kemewahan hidup duniawi). ${ }^{8}$ Salah satu karyanya dalam bidang pendidikan Islam yang sangat monumental adalah kitab "Ahwal al-Muta'allim wa Ahkam Mu'allimin wa al-Muta'allimin", sebagai kitab yang terkenal pada abad 4 dan sesudahnya.

Konsep pemikiran tujuan pendidikannya Al-Qabisy secara umum, sebagaimana dirumuskan oleh al-Jumbulati, yaitu: (1) mengembangkan kekuatan akhlak anak, (2) menumbuhkan rasa cinta agama, (3) berpegang teguh terhadap ajarannya, (4) mengembangkan perilaku yang sesuai dengan nilai-nilai yang murni, dan (5) anak dapat memiliki keterampilan dan keahlian pragmatis yang dapat mendukung kemampuan mencari nafqah. ${ }^{9}$ Sedangkan Abudin Nata memahami tujuan pendidikan Islam al-Qabisy bercorak normatif, yaitu mendidik anak menjadi seorang muslim yang mengetahui ilmu agama, sekaligus mengamalkan agamanya dengan menerapkan akhlak mulia. ${ }^{10}$ Dengan demikian,

5 Ibid, h. 186-187, lihat juaga pada Abuddin Nata, Pemikiran Para Tokoh Pendidikan Islam, (Jakarta: PT. Raja Grapindo Persada, 2003), h. 25-26.

${ }^{6}$ Al-Nu'my, op.cit., h.185

${ }^{7}$ Selain dikenal sebagai pemikir dalam bidang pendidikan, ia pun dikenal sebagai ulama hadis dan fiqih yang terkemuka di samannya, bahkan dalam bidang hadis sebagai ulama terkemuka dalam menghafal hadis dan alim dalam sanad dan matan. Abuddin Nata, loc.cit.

${ }^{8}$ Setelah wafat Ibnu Syilun, mufti negeri Tunis, ia terpaksa mengisi jabatan yang kosong ini karena dialah yang pantas mengisinya. Keluasan ilmunya pernah dipuji oleh Ibnu Syilun di hadapan orang banyak: bukalah pintu fatwa kepadanya, karena ia termasuk orang yang wajib memberi fatwa. Ia lebih berilmu dari orang lain yang ada di Qairawan, maka setelah wafatnya, ia menerima jabatan tersebut.Ibid.

${ }^{9}$ Ali al-Jumbulati,

${ }^{10}$ Abudin Nata, op.cit., h. 30 
dipahami bahwa pandangan intisari pendidikan al-Qabisy menurut Abudin Nata bukan hanya pada ranah pengetahuan kognitif, namun sekaligus pada ranah afektif dan psikomotorik.

\section{Biografi Rasyid Ridha dan Pandangan Umumnya tentang Pendidikan.}

Sayyid Muhammad Rasyid bin Ali Ridha bin Syamsuddin bin Baha'uddin al-Qalmuny al-Husaini, namun lebih dikenal dengan Muhammad Rasyid Ridha dan masih memiliki pertalian darah ahlul al-bait yakni Husain bin Ali bin Abi Thalib. Lahir di Qalamun (Kota Tripoli, Libanon) pada 22 J.Awal 1282 H (1865 M) dan ia wafat pada Agustus 1935. ${ }^{11}$ Ia hidup dalam lingkungan keluarga yang mengutamakan ilmu pengetahuan dan taat beragama, sehingga mendapatkan didikan dari orang tuanya membaca dan menghatamkam hafalan Al-Quran hingga usia 17 tahun.

Pada tahun 1882 M., belajar di Madrasah Rusydiyyah di Tripoli, kemudian pindah ke Madrasah al-Wathaniiyah al-Islamiyyah, milik pemerintahan Kota Tripoli yang dipimpin oleh Syaikh al-Jisr seorang alim ulama yang tergolong modernis. Namun mendapat tantangan dari pemerintah akibat konstalasi politik Kerajaan Usmani, hingga melanjutkan pendidikannya ke Madrasah Diniyyah di Kota yang sama, namun tetap melakukan komunikasi ilmiyah dengan gurugurunya (utamanya Syaik al-Jisr) saat di Madrasah sebelumnya, sehingga tetap memperoleh Ijazah, kemudian belajar hadis dan memperoleh ijazah dari Syekh Mahmud Kamil al-Rafi'u. selain itu, guru-gurunya adalah Sykeh Abd. Ghani alRafi', Syekh Muhammad al-Husain, dan Syekh Muhammad Abduh yang banyak mengispirasi pikirannya untuk bertemu dan berguru kepada Syekh ini.

Akibat besarnya tantangan untuk bertemu dengan Syekh Abduh, maka pada tahun 1898, melanjutkan pendidikannya ke Al-Azhar (Mesir) menjadi mahasiswa, hingga akhirnya secara bersama-sama menerbitkan majalah Al-Manar dan kemudian menyusun sekaligus melanjutkan Tafsir Al-Manar sepeninggal Syekh Muhammad Abduh pada tahun 1905 M., hingga ia pun wafat pada Agustus 1935 M., dengan meninggalkan beberapa karya-karyanya. ${ }^{13}$ Sebagai seorang

${ }^{11}$ Ibrahim Ahmad al-Adawy, Rasyid Ridha al-Imamul Mujtahid, (Kairo: Al-Muassah alMishriyyah al-Ammah li al-Ta'lif wal Anfa' wa al-Nasyr, t.th), h. 19.

${ }^{12} \mathrm{Ibid}$, h. 30. Selain menekuni aktifitas di sekolahnya, Ia pun mengikuti perkembangan dunia Islam melalui surat kabat "Al'Urwatul al-Wushqa" yang dikelola oleh Jamaluddin alAfghani (pembaharu dari Afghanistan) dan Muhammad Abduh (pembaharu dari Mesir). Dari kedua tokoh pemikir dan pembaharu inilah yang banyak menggerakkan akal dan pikirannya untuk bergambung dan berguru kepadanya.

13 Adapun karya-karyan yang dihasilka Rasyid Ridha, antara lain: Tarik al-Uastadz alImam asy-Skeh Muhammad Abduh (Sejarah Hidup Imam Syekh Muhammad Abduh), Nida' li al_jins al-Latif (Panggilan terhadap Kaum Wanita), Al-Wahy Muhammad (Wahyu kepada Muhammad SAW.), Munawarah al-Mushlih wa al-Muqallid (Dialog antara kaum pembaharu dan konservatif), dan Huquq al-Mar'ah al-Shalihah (hak-hak wanita muslim). Lihat Al-dawy, Ibid. 
guru/pendidik dan penanggugjawab pendidikan, Rasyid Ridha selalu berupaya merubah pola pikir masyarakat untuk lebih maju dan dinamis.

Salah satu pemikiran Pendidikan Islamnya, ia berpendapat bahwa umat Islam akan maju jika menguasai pendidikan. Olehnya itu, ia banyak menghimbau dan mendorong umat Islam untuk menggunakan kekayaan, potensi dan wewenangnya bagi pembanguna lembaga-lembaga pendidikan. Rasyid Ridha berupaya memajukan ide pengembangan kurikulum dengan memadukan muatan ilmu agama dan umum. Kepeduliannya ini dibuktikan dengan mendirikan lembaga pendidikan pada tahun 1912 di Kairo yang diberi nama Madrasah AdDakwah wal-Irsyad. $^{14}$ Dari setting biografi Rasyid Ridha dipahami bahwa pemikirannya dalam bidang pendidikan Islam lebih dominan dipengaruhi oleh inspirasi para guru, lingkungan pendidikannya selaku seorang guru, madrasahmadrasah tempat mengecap ilmu, dan madrasah yang dibangunnya.

\section{B. Konsep Pendidikan Al-Qabisy dan Rasyid Ridha; Koedukasi dan Kurikulum}

\section{Koedukasi Pendidikan}

Koedukasi, ${ }^{15}$ berasalal dari kata "co" yang berarti sama, sedangkan "ducation" adalah proses latihan dan pengembangan pengetahuan, keterampilan, keterampilan dan karakter. Utamanya dilaksanakan oleh lembaga formal melalui pengajaran dan latihan. ${ }^{16}$ Ali Al-Jumbulati lebih detail menjelaskan bahwa koedukasi berarti "co educational class" yang berarti percampuran antara laki-laki dan perempuan dalam suatu kelas. ${ }^{17}$ Dengan demikian, koedukasi yang dimaksud adalah sistem pendidikan yang dilakukan melalui proses belajar mengajar yang menggambungkan pria dana wanita dalam suatu ruangan (kelas), atau sering pula dikenal dengan pendidikan campuran.

Munculnya sistem koedukasi pendidikan dilandasi oleh diizinkannya keberadaan lembaga-lembaga Asing di negeri-negeri Islam, dan biasanya melaksanakan pendidikan melalui kebebasan penuh, tanpa pengawasan dari pihak pemerintah. ${ }^{18}$ Artinya, segala sistem operasional yang dijalankan terselubung ke dalam sistem pendidikan dan berkedok sebagai sistem pendidikan Islam.

\footnotetext{
${ }^{14}$ Yusran Asmuni, Pengantar Studi Pemikiran dan Gerakan pembaharuan dalam Dunia Islam, (Jakarta: Raja Grapindo Persada, 1996), h. 85.

${ }^{15}$ Menurut Echols, koedukasi berasal dari kata co-operate yang berarti kerjasama, dan kata educational bermakna pendidikan. Lihat John, M.M. Echols, An English- Indonesia Dictionary, diterjemahkan oleh Hasan Shadily dengan judul "Kamus Inggris-Indonesia" (Jakarta: Gramedia, 1988), h. 147.

${ }^{16}$ Noah Webster, Webster New Twentieth Century Dictionary of The English Language, (US of America: Williams Collins Publisher, 1972), h. 345 \& 576.

${ }^{17}$ Ali Al-Jumbulati, op. cit., h. 94.

${ }^{18}$ Koedukasi ini berlangusng pada masa Pemerintahan Muhammad Ali di Mesir, yang mana banyak mengirim pelajar Mesir ke Perancis dan banyak mendatangkan tenaga pendidik dari
} 
Al-Qabisiy menyatakan bahwa anak mempunyai hak sepenuhnya untuk belajar. Anak-anak tidak boleh disibukkan dengan pekerjaan sehingga mereka tidak sempat belajar Al-Qur'an dan menuntut ilmu pengetahuan. Ketika seorang laki-laki melapor kepada Sahnun (seorang pendidik abad III), bahwa ia tidak menghambat anaknya yang sedang menuntut ilmu dengan pekerjaan, tapi semua pekerjaan diselesaikan sendiri, Sahnun berkata kepadanya: "sesungguhnya fahala engkau lebih besar daripada fahala menunaikan ibadah haji dan ibadah jihad". Demikian Al-Qabisiy mengutip pendapat Sahnun tentang pentingnya pendidikan bagi anak remaja.

Al-Qabisiy tidak menyetujui materi pelajaran diberikan kepada anak perempuan selain pelajaran agama. Mengajar menulis dan syair bagi mereka dapat merusak kehidupan masa depan mereka. Ia memisahkan antara ilmu-ilmu yang patut diajarkan kepada anak perempuan dan ilmu-ilmu yang tidak boleh diberikan kepada mereka. Sebagian ilmu, kalau diajarkan kepada anak perempuan, dapat membawa kepada fitnah dan membahayakan kehidupannya sendiri. ${ }^{19} \mathrm{Al}-$ Qabisiy melihat bahwa syair-syair pada zaman kemajuan pendidikan Islam banyak yang mengarah pada pujian kecantikan perempuan, ghazal (cumbu rayu) dan kisah-kisah cinta muda-mudi. Maka ia melarang anak perempuan diberikan pelajaran mengarang syair-syair yang dikhawatirkan terjerumus ke dalam bahaya semacam itu.

Namun demikian, Al-Qabisy berpendapat bahwa tidak baik anak pria dan wanita bercampur dalam suatu kelas, karena dikhawatirkan rusak moralnya. ${ }^{20}$ Hal yang demikian dapat memperburuk tingkah laku anak-anak. Maka pemisahan tempat pendidikan wajib dilakukan demi terjaga keselamatan anak-anak dari penyimpangan-penyimpangan akhlak.

Tidak diketahui secara pasti tentang batasan umur tentang tidak bolehnya anak pria dan wanita bercampur dalam suatu kelas, namun al-Qabisy hanya mengatakan bahwa anak yang berusia muharriqah (masa pubertas/remaja) tidak memiliki ketenangan jiwa dan timbul dorongan yang kuat untuk mempertahankan jenis kelaminnya hingga ia sampai pada usia dewasa. Jika demikian, berarti anak dewasa dapat saja diadakan koedukasi pendidikan. Dapat dipahami pula, bahwa

luar, sehingga pemikkiran mereka tentang kemajuan Eropa saat itu banyak mempengaruhi kondisi pendidikan Mesir dan dunia Islam pada umumnya. Muhammad Abdul Alim Mursi, Al-Targhib fi al-Ta'lim fi Alamil al-Islamy, diterjemahkan oleh Majid Khan dengan judul "Westernisasi dalam Pendidikan Islam" (Jakarta:Fikahati Aneska, 1992), h.108.

${ }^{19}$ Al-Nu'my, op.cit., h. 216.

20 Pandangan serupa muncul dari Sachnun dan Abd. Alim Mursi yang menyolong pandangan al-Qabisy. Sachnun menyatakan bahwa guru yang paling tidak disukai adalah guru yang mengajar anak-anak wanita remaja kemudian dicampurkan dengan anak-anak pria remaja, maka akan mengakibatkan kerusakan fatal, terutama bagi wanita remaja. Demikian halnya Mursi, mengatakan bahwa menuntut ilmu pengetahuan merupakan hak bagi setiap wanita, namun tempat belajarnya harus terpisah karena mudharatnya lebih besar dibandingkan dengan manfaatnya. Ali AlJumbulati, lo.cit. 
al-Qabisy dapat saja menerima koedukasi, hanya saja dengan syarat koedukasi diterapkan dalam batas kewajaran dan tidak menjadikan kerusakan moral.

Sementara Rasyid Ridha yang dikenal sebagai seorang tokoh pembaharu abad XIX yang sangat memperhatikan pendidikan wanita, menolak adanya manfaat dari koedukasi. Ia melihat bahwa koedukasi bukan sekedar memiliki kekurangan, namun dapat mendatangkan malapetaka. Menurutnya, tradisi sistem edukasi merupakan adopsi dari orang-orang Eropa, bukan dari pengetahuan sempurna dan kebebasan berpikir, bukan pandangan yang halus dan lembut dan bukan pula dari hasil pertimbangan yang mendapatkan manfaat. ${ }^{21}$ Dengan demikian, Rasyid Ridha menolak adanya koedukasi itu dari segi negatifnya, dan tidak memandang adanya segi positif atau manfaat dari sistem koedukasi dalam pendidikan Islam.

Diasumsikan bahwa, Rasyid Ridha lebih menekankan pada tujuan atau hasil dari pendidikan campuran ini. Sehingga pandanganya yang lebih ekstrim ini mampu menghasilkan tokoh-tokoh pendidik dari wanita muslim, yang justru berupaya lebih memikirkan masa depan wanita. Artinya, implikasi yang muncul sesudahnya adalah merupakan upaya pemberontakan bagi wanita untuk lebih melihat sisi negatif dan positif dari sistem koedukasi ini. Apakah menimbulkan hasil yang cukup signifikan dan memiliki akses manfaat yang lebih luas terhadap perjuangan kaum wanita. Olehnya itu, pandangan Rasyid Ridha menggugah dunia pendidikan untuk lebih berhati-hati terhadap penerapan sistem koedukasi dalam pendidikan Islam, yang mesi dipahami secara arif, bijaksana dan kondisional dalam meraih tujuan pendidikan yang ideal pada setiap ruang dan waktu. Utamnya bagi pengelola lembaga pendidikan untuk super hat-hati dari kemungkinan hasil atau manfaat dari lembaga pendidikan bersangkutan.

Bertitik tolak pada pandangan pemikiran Al-Qabisy dan Rasyid Ridha di atas, berbeda halnya dengan Qasim Amin mengemukakan bahwa pendidikan kaum pria dan wanita tidak ada perbedaan dalam dimensi-dimensi tertentu, utamanya terhadap pembatasan dengan ketat pergaulan antara pria dan wanita, mereka harus diberikan kesempatan untuk bergaul, bertukarpikiran, serta bersamasama membangun pendidikan dan keutuhan negara. ${ }^{22}$ Tampaknya, ia menginginkan kemajuan kaum wanita dan memberikan kebebasan untuk mendapatkan kesamaan derajad dalam dunia pendidikan. Meskipun tidak ditemukan data secara tegas menyatakan bahwa sistem koedukasi dalam pendidikan, namun dapat dikongklusikan bahwa pemikiran tentang kebebasan dan kesamaan wanita Islam aktif sebagaimana wanita Barat, identik dengan tidak ada penolakan terhadap koedukasi dalam pendidikan.

\section{Kurikulum Pendidikan}

${ }^{21}$ Rasyid Ridha, Al-Jam'u baina al_Mas'alat al-Zukuran wa al-Madaris, (Al-Manar XXX No.2, 1348 H/1929 M.), h. 122.

${ }^{22}$ Qasim Amin, Tahrir al-Mar'ah, (Kairo: Dar al-Ma'arif al-Islamiyyah, t,th), h.41. 
Kurikulum pendidikan Islam merupakan bagian integral yang sangat vital dalam capaian hasil atau tujuan pendidikan. ${ }^{23}$ sehingga kemudian menghasilkan mutu pendidikan, ${ }^{24}$ yang lebih konfrehensif dan paripurna sebagai wujud penghambaan kepada Sang Pencipta dan Pemelihara terhadap keutuhan alamilmiyah. Kurikulum adalah sejumlah pengalaman, pendidikan, kebudayaan, sosial, keolaragaan dan kesenian yang disediakan oleh sekolah bagi murid di dalam dan diluar sekolah dengan maksud menolong mereka untuk berkembang dan mengubah tingkah laku mereka sesuai dengan tujuan pendidikan. ${ }^{25}$ Bahkan Hasan langgulung menggambarkan pada tiga materi yang harus ada dalam kurikulum yaitu, pertama, ilmu yang diwahyukan yang meliputi al-Qur'an dan Hadits serta bahasa Arab. Kedua, ilmu-ilmu yang mengkaji tentang manusia. Ketiga, adalah sains tabi'I yang meliputi fisika, biologi, astronomi dan lain sebagainya. Hanya saja menurut Hasan Langgulung pada esensinya ilmu itu satu yang membedakan adalah analisa. ${ }^{26}$

${ }^{23}$ Mengenai tujuan pendidikan kita tak dapat menarik satu kesimpulan saja. Sebab tujuan pendidikan yang secara umum di tentukan oleh zaman dan kebudayaan di tempat kita hidup dan ditentukan oleh pandangan hidup. Karena pandangan hidup manusia itu berlain-lainan, berbedabeda pula apa yang hendak dituju berbeda-beda pula. Menurut al-Abrasyi menghendaki tujuan pendidikan haruslah orang yang berakhlak mulia menurut Munir Marsyi berpendapat bahwa tujuan pendidikan ialah manusia sempurna. Abdul Fattah Jalal berpendapat bahwa tujuan pendidikan ialah terwujudnya manusia sebagai hamba Allah. Ahmad Tafisr, "Perkembangan Sisteim Pendidikan Islam”, Dinamika, 8 (Edisi Mei-Juni 1998), h. 20.

${ }^{24}$ Umar Tirtaraharja dalam sebuah analisisnya menguraikan bahwa hal yang dapat dijadikan sebagai standar penilaian sebuah lembaga pendidikan yang berkualitas adalah terletak pada hasil dan prosesnya. Dari segi hasilnya, paling tidak manusia output pendidikan harus cerdas otaknya (head), kuat, otot dan terampil tangannya (hand) serta mulia hatinya (heath). Sedangkan dari segi prosesnya adalah kemampuan sebuah lembaga pendidikan menghadapi masalah yang berkaitan dengan partisipasi, efisiensi, efektifitas dan relefansi pendidikan. Umar Tirtaraharja, Optinialisasi Sumber Daya Manusia dalam Meningkatkan Kualitas Pendidikan, "Makalah" disampaikan dalam Seminar Ikatan Mahasiswa DDI (IMDI), (Parepare: t.p., 1993.), h. 3-4.

${ }^{25}$ Dari definsi di atas, disimpulkan bahwa kurikulum itu mempunyai empat unsur atau aspek utama: (1) Tujuan dan obyektif yang ingin dicapai oleh pendidikan, (2) Pengetahuan dan informasi, data, aktivitas, dan pengalaman yang membentuk kurikulum itu, (3) Metode atau cara mengajar yang digunakan oleh guru untuk mengajarkan dan mendorong murid belajar dan membawa mereka ke arah yang dikehendaki oleh kurikulum, dan (4) Metode dan cara penilaian yang digunakan dalam mengukur dan menilai kurikulun serta hasil pembelajaran pendidikan yang dirancang dalam kurikulum, seperti ujian catur wulan. Hasan Langgulung, Peralihan Paradigma dalam Pendidikan Islam dan Sains Sosial, h. 241.

${ }^{26}$ Ibid, h. 36. Sedangkan dalam Undang-Undang RI., Nomor 20 Tahun 2003, tentang Sistem Pendidika Nasional Pasal 1 ayat 19, disebutkan bahwa kurikulum adalah seperangkat rencana dan pengaturan mengenai tujuan, isi, tambahan pelajaran serta cara yang digunakan sebagai pedoman penyelenggaraan kegiatan pembelajaran untuk mencapai tujuan pendidikan tertentu. Lihat Mashur Mushlich, Seri Standar Nasional Pendidikan KTSP (Kurikulum Tingkat Satuan pendidikan) Dasar Pemahaman dan Pengembangan, (Jakarta: Bumi Aksara, 2008), h. 1 
Pada dasarnya, implementasi kurikulum pada suatu sekolah merupakan suatu alat atau usaha mencapai tujuan-tujuan pendidikan yang diinginkan sekolah tertentu yang dianggap cukup tepat dan krusial untuk dicapai. Salah satu langkah yang harus dilakukan adalah meninjau kembali tujuan yang selama ini digunakan oleh sekolah. Dalam pencapaian tujuan pendidikan yang dicita-citakan, tujuantujuan tersebut harus dicapai secara bertahap yang saling mendukung. Sedangkan keberadaan kurikulum disini adalah sebagai alat untuk mencapai tujuan pendidikan.

Sebagaimana substansi obyek bahasan ini, Al-Qabisiy membagi tujuan pengajaran kepada dua tujuan utama; yaitu tujuan agama dan tujuan akhlak. Ini dipahami dari tulisan-tulisan yang dikemukakannya yang dianalisis kemudian oleh para peneliti yang mengkaji ide-idenya di kemudian hari.

Al-Qabisiy selalu menyeru, di manapun ia berada, agar ummat Islam harus berpegang teguh pada dasar-dasar agama. Ia selalu mengisyaratkan pada ummat Islam untuk memperhatikan kelebihan para pemimpin periode pertama ummat Islam ini. Ummat Islam pertama amat memperhatikan Al-Qur'an, mencari guru-guru yang mengajar Al-Qur'an dan mendalami maksud kandungan isi AlQur'an. Setelah mengajarkan Al-Qur'an kepada anak-anak, diberikan pengajaran praktis yaitu cara-cara berwudluk dan praktek shalat. Anak perlu dilatih secara kontinyu untuk melaksanakan shalat sampai ia merasa senang mengerjakan ibadah dan merasa bersalah jika ia meningalkannya. Pengajaran Al-Qur'an, menurut AlQabisiy, adalah suatu ilmu yang kekal yang harus dimiliki oleh anak-anak dan itulah kejayaan yang paling abadi jika anak memperolehnya. ${ }^{27}$ Pernyataan AlQabisiy di atas dapat dipahami bahwa kalau anak-anak menghafal Al-Qur'an dan memahami maksudnya, maka itu kelak akan menjadi inspirasi berharga untuk mengembangkan sejumlah ilmu pengetahuan islami yang dikuasainya dan tidak akan melenceng dari tujuan-tujuan Islam. Anak dapat saja menekuni matiq, filsafat, Ilmu Pengetahuan Alam, matemateka dan lain-lain sebagainya sementara ia memilki asas Al-Qur'an yang kuat. Maka bidang apa saja yang dikembangkannya kelak ia selalu berlandaskan pada asas yang kuat yaitu dengan berorientasi pada ayat-ayat Al-Qur'an.

Menyangkut dengan pendidikan akhlak, Al-Qabisiy meminta para pendidik agar berpegang pada nilai-nilai dan prinsip-prinsip yang didasarkan kepada Al-Qur'an dan Sunnah. Ia berkata: "siapa yang mengajar anaknya dan memperbagus pengajarannya dan siapa saja yang mendidik anaknya serta memperbagus pendidikannya, orang tersebut telah berbuat baik kepada anaknya dan akan mendapat fahala di sisi Allah". Al-Qabisiy menyatakan bahwa antara pendidikan dengan pengajaran saling mengisi. Akhlak mesti dibina oleh keluarga, lembaga pendidikan dan masyarakat umum. Kalau anak menyimpang ataupun melakukan hal-hal yang buruk, itu lebih disebabkan oleh keluarga yang tidak

${ }^{27}$ Al-Nu'my, op.cit. h. 202-204 
melaksanakan kewajiban mereka. Anak-anak yang telah menyimpang dari prilaku agama perlu diberikan hukuman serta mendidik ke arah yang benar. ${ }^{28}$

Ketika membahas isi sebuah kurikulum pendidikan, Al-Qabisi mengklasifikasi pengajaran ke dalam dua bagian besar yaitu ilmu-ilmu asasi/wajib (ijbari) dan ilmu-ilmu yang bukan asasi/tidak wajib (ikhtiyariy). Ilmuilmu tersebut meliputi ilmu-ilmu berikut: ${ }^{29}$

1) Al-Quran. Al-Qur'an merupakan mata pelajaran yang asasi dan wajib dipelajari oleh setiap anak pada setiap ma'had. Al-Qur'an wajib diperhafalkan kepada anak-anak, karena Al-Qur'an merupakan modal dasar dalam upaya mengembangkan pengetahuannya di masa yang akan datang.

2). Fiqih. Fiqih yang dimaksudkan oleh al-Qabisiy adalah dasar-dasar hukum Islam yang wajib diketahui oleh setiap anak agar ia dapat melaksanakan kewajiban-kewajiban yang dibebankan kepadanya. Guru wajib membebankan kepada mereka untuk melaksanakan shalat ketika mereka berumur tujuh tahun, demikian juga mengajarkan cara berwudluk yang benar. Selain itu perlu juga diberikan dasar-dasar tauhid kepada mereka agar mereka mengagumi Allah sebagai Tuhan mereka.

3). Akhlak. Akhlak sangat penting diberikan kepada anak-anak, karena sisi ini ada yang menyangkut dengan Allah sendiri dan ada juga terkait dengan sesama manusia. Anak-anak perlu ditanam dalam diri mereka sifat-sifat yang baik sejak dini dan diarahkan tingkah laku mereka pada jalan yang benar.

4). Khat, Mengheja dan Membaca. Anak-anak sangat perlu mempelajari khat serta dapat mengheja dan membaca Al-Qur'an. Hal ini penting sekali dalam pengajaran Al-Qur'an. Guru, menurut Al-Qabisiy, wajib menuntun anak-anak pada dasar-dasar cara membaca Al-Qur'an sesuai dengan cara bacaan yang benar sampai mereka dapat membaca dengan bagus.

5). Bahasa Arab. Yang dimaksud dengan bahasa Arab di sini adalah dasardasar ilmu nahwu, namun bukan pembahasannya yang mendetil. Tujuannya adalah agar anak-anak dapat membaca setiap teks dengan benar dan dapat memahami kesalahan bacaan.

Sedangkan ilmu-ilmu yang tidak termasuk dalam katagori asasi (ikhtiyariy), sebagai berikut: ${ }^{30}$

1) Ilmu Hisab (berhitung). Al-Qabisiy tidak menuntut pada guru untuk mengajar mata pelajaran ini sebagai mata pelajaran yang wajib, tapi guru boleh memberi pelajaran ini sebagai pilihan pada murid-muridnya. Ia mengaitkan urgensi pelajaran ini dengan tujuan keagamaan, karena

\footnotetext{
${ }^{28}$ Ibid., h. 203-205

${ }^{29} \mathrm{Ibid}$, h. $230-236$

${ }^{30} \mathrm{Ibid}$, h. $236-242$
} 
mempelajarinya akan membantu untuk memahami ilmu faraidl (pembagian pusaka). Nampaknya, Al-Qabisiy menjadikan mata pelajaran ini diberikan pada jenjang pendidikan menengah dan pendidikan tinggi.

2) Sastra Arab. Kalau dasar-dasar bahasa Arab dianggap asas, tapi mengkaji sastra adalah ilmu yang bukan asasi lagi. Mempelajari syair, prosa dan pidato tokoh-tokoh Arab merupakan mata pelajaran pilihan. Menghafal syair-syair dapat membantu anak-anak untuk memngembangkan kemampuan bahasanya dan dapat berbicara dengan bahasa yang santun. Faedah lain dari syair adalah menjadi hiburan pada waktu-waktu sengggang.

3) Sejarah. Sejarah bukan materi pelajaran yang asasi menurut Al-Qabisiy, tapi pelajaran sejarah dapat melatih anak-anak untuk bertingkah laku yang baik dan berperilaku mulia. Sejarah orang-orang yang baik sangat berguna bagi anak-anak untuk menjadi pedoman hidup bagi mereka. Jadi pelajaran sejarah, menurut Al-Qabisiy lebih ditekankan pada agar anakanak bercermin pada perbuatan-perbuatan yang baik.

Sedangkan Rasyid Ridha lebih menekankan kurikulum pada aspek muatan kurikulum ilmu agama dan umum, sebagaimana ia terapkan di Madrasah al-Dakwah wa al-Irsyad. Implementasi dari kurikukum yang ia terapkan di Madrasah tampaknya memilah antara ruang ilmu peribadatan yang wajib dilakukan pada setiap pelajar. Dalam hal ini aspek pertama, masalah materi Alquran dan Hadis harus diajarkan dan diimpelementasikan secara asasi kepada lingkup lembaga pendidikan, tanpa ditolerir lagi meskipun situasi masyarakat terus berubah dan berkembang. Sementara aspek kedua, yakni aspek mu'amalah (yang berhubungan dengan manusia), seperti ilmu-ilmu yang berhubungan dengan keadilan, persamaan, politik, ilmu alam, dan lain-lain, diserahkan kepada komponen pelaksana/pengelola dan penanggungjawab pendidikan untuk menentukan potensi dan kondisi yang dihadapi peserta didik, selama tidak menyimpang dari prinsip-prinsip dasar ajaran Islam. ${ }^{31}$

Penekakan Rasyid Ridha terhadap kurikulum Qur'any, dengan alasan bahwa Al-Qur'an merupakan kalam Allah yang telah diwahyukan-Nya kepada nabi Muhammad bagi seluruh umat manusia. Al-Qur'an merupakan petunjuk yang lengkap, pedoman bagi manusia yang meliputi seluruh aspek kehidupan manusia yang bersifat universal. Keuniversalan ajarannya mencakup ilmu pengetahuan yang tinggi sekaligus merupakan mulia yang esensinya tidak dapat dimengerti, kecuali bagi orang yang berjiwa suci dan berakal cerdas. ${ }^{32}$ Al-Qur'an merupakan sumber pendidikan yang terlengkap, baik itu pendidikan

31 Al-Adlawy, op.cit., 25-26. Lihat pula Rasyid Ridhah, op.cit., h. 139-140.

${ }^{32}$ Muhammad Rasyid Ridha, Tafsir al-Manar, Mesir, Dar al-Manar, IV/1373, Juz I, h. 262. 
kemasyarakatan (sosial), moral (akhlak), maupun spiritual (kerohanian), serta material(kejasmanian) dan alam semesta. Al-Qur'an merupakan sumber nilai yang absolut dan utuh. Eksistensinya yang tidak pernah mengalami perubahan. Kemungkinan terjadi perubahan hanya sebatas interpretasi manusia terhadap teks ayat yang menghendaki kedinamisan pemaknaannya, sesuia dengan konteks zaman, situasi, kondisi, dan kemampuan manusia dalam melakukan interpretasi. Ia merupakan pedoman normatif teoritis bagi pelaksanaan pendidikan Islam yang memerlukan penafsiran lebih lanjut bagi operasional pendidikan Islam.

Menurut Rasyid Ridha, bahwa cakupan materi kurikulum mencakup seluruh dimensi manusia dan mampu menyentuh seluruh potensi manusia, baik itu motivasi untuk mempergunakan pancaindra dalam menafsirkan alam semesta bagi kepentingan formulasi lanjut pendidikan manusia (pendidikan Islam), motivasi agar manusia mempergunakan akalnya, lewat tamsilan-tamsilan Allah SWT. AlQur'an, maupun motivasi agar manusia mempergunakan hatinya untuk mentransfer nilai-nilai pendidikan Ilahiah, dan lain sebagainya. Semua proses ini merupakan sistem umum pendidikan yang ditawarkan Al-Qur'an, agar manusia dapat menarik kesimpulan dan melaksanakan semua petunjuk tesebut dalam kehidupannya.

\section{KESIMPULAN}

Menyimak beberapa uraian bahasan yang telah dikemukakan di atas, maka dapat disimpulkan, sebagai berikut:

1. Abu Al-Hasan Muhammad bin Khalaf Al-Ma'arifi Al-Qairawaniy, (dikenal Al-Qabisiy), lahir di Kota Qairawan Tunisia pada 324 H/935 M, dan wafat $403 \mathrm{H} / 1012 \mathrm{M}$. Merupakan pemikir pendidikan Islam di samannya yang berpengaruh dalam dunia Islam. Konsep pemikiran tujuan pendidikannya AlQabisy secara umum, yaitu: (1) mengembangkan kekuatan akhlak anak, (2) menumbuhkan rasa cinta agama, (3) berpegang teguh terhadap ajarannya, (4) mengembangkan perilaku yang sesuai dengan nilai-nilai yang murni, dan (5) anak dapat memiliki keterampilan dan keahlian pragmatis yang dapat mendukung kemampuan mencari nafqah.

2. Sayyid Muhammad Rasyid bin Ali Ridha bin Syamsuddin bin Baha'uddin alQalmuny al-Husaini (dikenal Muhammad Rasyid Ridha), Lahir di Qalamun Tripoli, Libanon, 1282 H/1865 M., wafat tahun 1935 M. Dalam dunai pemikiran Pendidikan Islam, menganggap bahwa kemajuan umat Islam terletak pada Pendidikan, sehingga Ia menghimbau dan mendorong umat Islam untuk menggunakan kekayaan dan wewenangnya bagi pembangunan lembaga-lembaga pendidikan.

3. Koedukasi berarti "co educational class" yang berarti percampuran antara laki-laki dan perempuan dalam suatu kelas, sistem pendidikan yang dilakukan melalui proses belajar mengajar yang menggambungkan pria dan wanita dalam suatu ruangan (kelas), atau sering pula dikenal dengan pendidikan campuran. Sedangkan kurikulum pendidikan Islam merupakan bagian 
integral yang sangat vital dalam capaian hasil atau tujuan pendidikan. Kemudian menghasilkan mutu pendidikan, yang lebih konfrehensif dan paripurna sebagai wujud penghambaan kepada Sang Pencipta dan Pemelihara terhadap keutuhan alam-ilmiyah.

4. Penerapan sistem koedukasi dalam pendidikan Islam bagi Al-Qabisy bahwa tidak baik anak pria dan wanita bercampur dalam suatu kelas, karena dikhawatirkan rusak moralnya, maka pemisahan tempat pendidikan wajib dilakukan demi terjaga keselamatan anak-anak dari penyimpanganpenyimpangan akhlak. Sedangkan Rasyid Ridha menolak adanya manfaat dari koedukasi, dan menganggap bahwa koedukasi bukan sekedar memiliki kekurangan, namun dapat mendatangkan malapetaka, utamanya kaum wanita.

5. Al-Qabisy mengklasifikasi kurikulum pendidikan Islam ke dalam dua bagian besar yaitu ilmu-ilmu asasi/wajib (ijbari) dan ilmu-ilmu yang bukan asasi/tidak wajib (ikhtiyariy). Sedangkan Rasyid Ridha lebih menekankan kurikulum pada aspek muatan kurikulum ilmu agama dan umum, Implementasi dari kurikukum yang ia terapkan di Madrasah tampaknya memilah antara ruang ilmu peribadatan yang wajib dilakukan pada setiap pelajar. Dalam hal ini aspek pertama, masalah materi Alquran dan Hadis harus diajarkan dan diimpelementasikan secara asasi kepada lingkup lembaga pendidikan. Sementara aspek kedua, yakni aspek mu'amalah, diserahkan kepada komponen pelaksana/pengelola dan penanggungjawab pendidikan yang dapat dikondisionalkan.

\section{DAFTAR PUSTAKA}

al- Abrasyi, Athiya, Dasar-Dasar Pokok Pendidikan Islam, Jakarta, Bulan Bintang, 1984.

al- Adawy, Ibrahim Ahmad. Rasyid Ridha al-Imamul Mujtahid, (Kairo: AlMuassah al-Mishriyyah al-Ammah li al-Ta'lif wal Anfa' wa al-Nasyr, t.th

al-Nu'my, Abdullah al-Amin. Kaedah dan Tekhnik Pengajaran Menurut Ibnu Khaldun dan Al-Qabisy. Jakarta: t.pt., 1995.

Amin, Qasim. Tahrir al-Mar'ah. Kairo: Dar al-Ma'arif al-Islamiyyah, t,th

Asmuni, Yusran. Pengantar Studi Pemikiran dan Gerakan pembaharuan dalam Dunia Islam. Jakarta: Raja Grapindo Persada, 1996.

Echols, John, M.M., An English- Indonesia Dictionary, diterjemahkan oleh Hasan Shadily dengan judul "Kamus Inggris-Indonesia". Jakarta: Gramedia, 1988. 
Jalaluddin, Psikologi Agama . Cet.I; Jakarta: Grafindo Persada, 1996.

al- Jumbulati, Ali. Dirasatun Muqaranatun fit Tarbiyyatil Islamiyyah, terj. M. Arifin, dengan judul Perbandingan Pendidikan Islam. Jakarta: Rineka Cipta, 1994.

Langgulung, Hasan. Pendidikan dan Peradaban Islam; Suatu Analisa SosioPsikologi, Jakarta, Pustaka Al-Husna, 1985.

, Peralihan Paradigma dalam Pendidikan Islam dan Sains Sosial. Jakarta: Pustakan Husna, 2004.

Mappanganro, Implementasi Pendidikan Islam di Sekolah. Ujungpandang: Yayasan Ahkam, 1996.

Mursi, Muhammad Abdul Alim. Al-Targhib fi al-Ta'lim fi Alamil al-Islamy, diterjemahkan oleh Majid Khan dengan judul "Westernisasi dalam Pendidikan Islam". Jakarta: Fikahati Aneska, 1992.

Mushlich, Mashur. Seri Standar Nasional Pendidikan KTSP (Kurikulum Tingkat Satuan pendidikan) Dasar Pemahaman dan Pengembangan. Jakarta: Bumi Aksara, 2008.

Nahdlawi, Abdurrahman. Ushul al-Tarbiyah al-Islamiyah wa Asalibuha fi al-Bayt wa al-Madrasah wa al-Mujtama' diterjemahkan oleh Shibabuddin dengan judul Pendidikan Islam di Rumah, Sekolah dan Masyarakat. Cet. II; Jakarta: Gema Insani Press, 1995.

Nata, Abuddin. Pemikiran Para Tokoh Pendidikan Islam. Jakarta: Raja Grapindo Persada, 2003

Ridha, Muhammad Rasyid. Tafsir al-Manar, Mesir, Dar al-Manar, IV/1373, Juz I. ,. Al-Jam'u baina al-Mas'alat al-Zukuran wa al-Madaris. Al-Manar XXX No.2, 1348 H/1929 M.

Tafisr, Ahmad. "Perkembangan Sisteim Pendidikan Islam", Dinamika, 8. Edisi Mei-Juni 1998

Tirtaraharja, Umar. Optinialisasi Sumber Daya Manusia dalam Meningkatkan Kualitas Pendidikan, "Makalah" disampaikan dalam (IMDI). Parepare: t.p., 1993.

Webster, Noah. Webster New Twentieth Century Dictionary of The English Language. US of America: Williams Collins Publisher, 1972. 